\title{
Variation of Stem Radius in Response to Defoliation in Boreal Conifers
}

\section{OPEN ACCESS}

Edited by:

Veronica De Micco,

University of Naples Federico II, Italy

Reviewed by:

Jesús Julio Camarero, Consejo Superior de Investigaciones Científicas (CSIC), Spain

Olivier Bouriaud,

Ştefan cel Mare University

of Suceava, Romania

${ }^{*}$ Correspondence:

Lorena Balducci

Lorena.Balducci1@uqac.ca

Specialty section:

This article was submitted to

Forest Growth,

a section of the journal

Frontiers in Forests and Global

Change

Received: 27 September 2021 Accepted: 05 November 2021

Published: 16 December 2021

Citation:

Balducci L, Rozenberg P and

Deslauriers A (2021) Variation of Stem

Radius in Response to Defoliation

in Boreal Conifers.

Front. For. Glob. Change 4:784442.

doi: $10.3389 / f f g c .2021 .784442$

\section{Lorena Balducci $^{1 *}$, Philippe Rozenberg ${ }^{2}$ and Annie Deslauriers ${ }^{1}$}

' Département des Sciences Fondamentales, Université du Québec à Chicoutimi, Chicoutimi, QC, Canada, ${ }^{2}$ INRAE, ONF, UMR 0588 BioForA, Orléans, France

In the long term, defoliation strongly decreases tree growth and survival. Insect outbreaks are a typical cause of severe defoliation. Eastern spruce budworm (Choristoneura fumiferana Clem.) outbreaks are one of the most significant disturbances of Picea and Abies boreal forests. Nevertheless, in boreal conifers, a 2-year defoliation has been shown to quickly improve tree water status, protect the foliage and decrease growth loss. It suggests that defoliation effects are time-dependent and could switch from favorable in the short term to unfavorable when defoliation duration exceeds 5-10 years. A better understanding of the effect of defoliation on stem radius variation during the needle flushing time-window could help to elucidate the relationships between water use and tree growth during an outbreak in the medium term. This study aims to assess the effects of eastern spruce budworm (Choristoneura fumiferana Clem.) defoliation and bud phenology on stem radius variation in black spruce [Picea mariana (Mill.) B.S.P.] and balsam fir [Abies balsamea (L.) Mill.] in a natural stand in Quebec, Canada. We monitored host and insect phenology, new shoot defoliation, seasonal stem radius variation and daytime radius phases (contraction and expansion) from 2016 to 2019. We found that defoliation significantly increased stem growth at the beginning of needle flushing. Needles flushing influenced the amplitude and duration of daily stem expansion and contraction, except the amplitude of stem contraction. Over the whole growing season, defoliation increased the duration of stem contraction, which in turn decreased the duration of stem expansion. However, the change (increase/decrease) of the duration of contraction/expansion reflects a reduced ability of the potential recovery from defoliation. Black spruce showed significantly larger 24-h cycles of stem amplitude compared to balsam fir. However, both species showed similar physiological adjustments during mild stress, preventing water loss from stem storage zones to support the remaining needles' transpiration. Finally, conifers react to defoliation during a 4-year period, modulating stem radius variation phases according to the severity of the defoliation.

Keywords: stem radius variation, Picea mariana, Abies balsamea, eastern spruce budworm, defoliation

Abbreviations: SBW, eastern spruce budworm. 


\section{KEY MESSAGE}

- Stem radius variation is a proxy for the effect of defoliation by eastern spruce budworm on stem radial growth in mature black spruces [Picea mariana (Mill.) B.S.P.] and balsam firs [Abies balsamea (L.) Mill.] stand after a 4-year defoliation period. The defoliation significantly increased stem growth at the onset of needles flushing. Changes in duration of daily fluctuation of stem radial variation are early signals of mild defoliation stress in both species.

\section{INTRODUCTION}

Insects outbreaks are considered a significant natural biotic disturbance in boreal forests. In Canada, forest areas affected by bark beetle and defoliators outbreaks have reached $16.6 \mathrm{M}$ hectares per year during the past 40 years (Kautz et al., 2017). The nature of disturbance on host trees depends on feeding strategies (e.g., sap- or nectar feedings, woodboring, leaf-mining, and leaf snipping), population density, and insect morphology and phenology (e.g., number and size changes, according to the life stages-specific, increased foraging) (Leather, 1996; Hochuli, 2001; Cooke et al., 2007; Kalcsits and Northfield, 2020). On the other hand, the host responses to damage involve complex mechanisms altering plant physiology and wood anatomy. For example, defoliation-reduced leaf area improves water relations by limiting excessive transpiration (Hart et al., 2000; Hubbard et al., 2013), but reduces photosynthetic activity and carbon supply (Eyles et al., 2013; Jacquet et al., 2014), and thus decreases tree growth (Pinkard et al., 2007; Jacquet et al., 2012). However, the definition of the temporal pattern of insect attack's (frequency, duration, intensity, and timing) is crucial, because it can cause from negligible to major tree damages that can lead to tree death.

Eastern North America boreal forests are mainly defoliated by the eastern spruce budworm (SBW) [Choristoneura fumiferana (Clem.)] (MacLean, 1980; Morin, 1994). This native defoliator cyclically affects balsam fir [Abies balsamea (L.) Mill.], as the primary host, and black spruce [Picea mariana (Mill.) BSP], as a secondary host (Régnière et al., 1989; Nealis and Régnière, 2004; Virgin and MacLean, 2017). Over the nineteenth and twentieth centuries, historical tree ring studies observed 25-40year periodicity between successive defoliation peaks (Royama, 1984; Jardon et al., 2003). A simplified «model of defoliation outbreak » considers 30 years as average outbreak interval (Gray et al., 2000). The active feeding damage is noticeable during the first 18 years of the outbreak interval: the intensity of defoliation increases up to $100 \%$ for 7 years; it remains severe during several years then decreases progressively until the next defoliation peak (Gray et al., 2000). However, current climate change scenarios predict a shift in frequency and impact of insect outbreaks, with a potential reduction on forest productivity (Pureswaran et al., 2015).

A recent study showed that a 2-year defoliation increased internal water availability and reduced mortality in young trees (Bouzidi et al., 2019). Other researches indicated a significant reduction in tree-ring width only after 5-10 years of defoliation, although twig water content, supporting tree growth remained mainly stable with only a slight decrease (Candau et al., 1998; Deslauriers et al., 2015). However, a recent study showed that the first wood anatomical changes appeared after 4 years of defoliation (Paixao et al., 2019). These changes in the wood anatomical structure and mechanical properties could influence water movement well before the subsequent growth reduction (Lachenbruch and McCulloh, 2014). However, the links between the physiological shift following defoliation and its effect on internal water reserves and tree growth, and the favorable and unfavorable responses observed between successive defoliation events, remain unclear.

Crown and stem contribute differently to water movement and storage in plant tissues. In a healthy tree, all plant compartments such as roots, stem, branches, and needles store water, while water is lost due to needles transpiration (Meinzer et al., 2001). Stem radial dimension fluctuates with a diurnal and reversible pattern of dehydration and replenishment (Turcotte et al., 2011), according to daily fluctuations of water demand caused by transpiration and photosynthetic carbon gain (De Schepper et al., 2012; De Swaef et al., 2013). Moreover, the irreversible radial growth of the stem which is one of the consequences of photosynthetic carbon gain requires swelling of water reserves (Deslauriers et al., 2003). Seasonal change of stem dimensions in mature stands of boreal conifers has been observed during a 3-year drought (Belien et al., 2014). During a 1 -year greenhouse studies in young trees repeated once, a 23-day controlled drought reduced radial growth more than a 20-days defoliation (Bouzidi et al., 2019; Deslauriers et al., 2019). To our knowledge, no attention has been paid to stem radius variation according to the level of defoliation in natural stands, which is essential given that a potential decrease in forest productivity is expected during an insect outbreak.

Host tree species are characterized by different budburst timings (Pureswaran et al., 2015). In Fennoscandia, high phenological synchrony of spring budburst and insect played a crucial role in the first years of outbreak spread (Jepsen et al., 2009). This could be due to temporal convergence between the appearance of current-year foliage (the optimal foraging source) and active insect feeding period, which determines the success of the insect establishment (Fuentealba et al., 2017b) at the cost of increased defoliation. Thus, mismatched host-insect phenology may reduce the negative effects of defoliation (Ren et al., 2020), potentially promoting physiological reactions in trees (Deslauriers et al., 2015, 2019; Bouzidi et al., 2019). Some of these physiological reactions concern plant water status during and after the defoliation peak: leaf water potential decreases during active defoliation. In contrast, after the defoliation period, it was less negative in defoliated trees than in undefoliated ones (Bouzidi et al., 2019). In the last outbreak (1970s1980s), phenological mismatch between budburst and insect emergence reduced defoliation more in black spruce than in balsam fir (Volney and Fleming, 2000; Nealis and Régnière, 2004). However, host-insect phenology was better synchronized under warmer experimental temperatures (Ren et al., 2020), suggesting a potential increase of intensity and duration of insect outbreaks under global warming. Hence, we hypothesize that 
such increased defoliation may affect patterns of stem radial variation in spring, which may also have consequences later during the growing season.

In this study, we investigated the effect of eastern spruce budworm defoliation on the variation of stem radius during a 4-year period. We selected mature stands of two conifer species, black spruce [Picea mariana Mill. BSP] and balsam fir [Abies balsamea (L.) Mill.]. We tested whether the seasonal pattern of stem radius variation and its daily contraction and expansion was modified, and if it was more affected before, during or after the time-window during which needles flushing exposes buds to defoliation. We hypothesized that (i) increased defoliation reduces seasonal and daily stem radius variation; (ii) in defoliated trees, during the needles flushing time-window, the amplitude and duration of daily contraction and expansion are reduced; and (iii) patterns of stem contraction and expansion over the defoliation years are more altered in balsam fir than in black spruce.

\section{MATERIALS AND METHODS}

\section{Study Site and Tree Selection}

The study was conducted in a permanent site located in the Monts-Valin National Park (QC, Canada), called GP, Gaspard $\left(48^{\circ} 34^{\prime} \mathrm{N} ; 70^{\circ} 53^{\prime} \mathrm{W}\right)$. The site is characterized by a mixed natural stand of black spruce [Picea mariana (Mill.) B.S.P.] and balsam fir [Abies balsamea (L.) Miller] at $227 \mathrm{~m}$ above sea level (4-8\% slope) located in the balsam fir-yellow birch forest bioclimatic domain (Saucier et al., 2009). The undergrowth is a typical mixed vegetation with herbaceous and ericaceous shrub species (Cornus canadensis L., Gaultheria hispidula L., Kalmia angustifolia L., Rhododendron groenlandicum Oeder Kron and Judd, and Vaccinium myrtilloides Ait.). As the study area is in the transition zone between northern temperate forest and boreal forest, the climate is dry and moderately cold during the winter, with moist and warm summers. Mean annual air temperature and precipitation are $2.8^{\circ} \mathrm{C}$ and $931 \mathrm{~mm}$, respectively (1981-2010 Climate normals of nearby station with data, Environment Canada). Extreme minimum and maximum temperature reaches -43.3 and $38.4^{\circ} \mathrm{C}$, respectively, and the average frost-free period length is 123 days (1981-2010 Climate normals, Environment Canada).

Bud and larval phenology and stem radius variation were monitored over a 4-year period (2016-2019). Three dominant or co-dominant trees per species were randomly selected in the site stands, having low defoliation level of eastern spruce budworm (SBW) [Choristoneura fumiferana (Clemens)] (Ministère des Forêts de la Faune et des Parcs, 2015).

\section{Climate Data Collection}

A weather station was installed at the site in a forest gap in order to measure the microclimatic conditions. Air temperature $\left({ }^{\circ} \mathrm{C}\right)$ and rainfall $(\mathrm{mm})$ were collected at 15 -min intervals and recorded as hourly averages by means of CR1000 data-loggers (CAMPBELL SCIENTIFIC Corporation, Logan, UT, United States). For technical problems during winter months, absolute maximum and minimum air temperature $\left({ }^{\circ} \mathrm{C}\right)$ were referred to different duration's observation (Table 1).

\section{Phenological Measurements and Defoliation}

From 2016 until 2019, we measured budbreak phases between May and July once a week on apical shoots of the two northfacing and two south-facing permanent branches per tree in the low-crown (three tree species), located generally between a height of 1.5 to $2.5 \mathrm{~m}$ above the ground. On each apical shoot, we monitored bud development following Dhont et al. (2010): (1) open bud; (2) elongated bud; (3) swollen bud; (4) translucent bud; (5) split bud; (6) exposed shoot. At the same time, we determined the larval development stages of eastern spruce budworm based on the size of the head capsule of the larvae (from larval stage development L2 to L6), three larvae were randomly observed in each branch (McGugan, 1954). Larva L2 spends autumn and winter in hibernation and emerges in the spring, the insect intensively feeds and grows on shoots during larval stages L4 to L6 (Pureswaran et al., 2015). We also visually assessed the defoliation levels on current-year foliage of apical shoots collected at the mid-crown in each tree during the growing season (except in 2018 when for a technical problem we monitored defoliation only in September) using the shootcount method based on six defoliation classes (Piene et al., 1981; MacLean and Lidstone, 1982) and calculated the median percentage of defoliation for each tree.

\section{Stem Radius Variations Measurements}

We used point dendrometers Radius type (Ecomatik, Munich, Germany) to monitor stem radius variation from January 2016 until December 2019. We installed the dendrometers at $1.3 \mathrm{~m}$ height on the north side of the trunk on three tree species. Measurements were taken every $15 \mathrm{~min}$ and stored in CR1000 data-loggers (CAMPBELL SCIENTIFIC Corporation, Logan, UT, United States). The resolution and accuracy of the dataloggerdendrometer equipment was 0.2 and $1.5 \mu \mathrm{m}$, respectively. To compare the same temporal interval among years, we selected from each annual record measurements from April to October corresponding to the growing season in our study region, as reported in Belien et al. (2014).

\section{Statistical Analyses}

We estimated the probability of co-occurrence of time-windows of needles flushing (phases 3-6) and feeding larvae (fourth to sixth instars) for each tree species during each growing season from 2016 until 2019 using SAS (SAS 9.4, SAS Institute, Inc., Cary, NC). The classification method adopted a parametric approach based on multivariate normal distributions within each group to derive discriminant quadratic functions. We assumed unequal variances between groups using the observed withingroup covariance matrices (Ren et al., 2020). For referring to the host phenology in the statistical analyses, we considered the budburst in three periods, based on the days before, during and 
TABLE 1 | Climate characteristics of the experimental site (GP, Gaspard, Canada).

\begin{tabular}{|c|c|c|c|c|c|}
\hline Site & $\begin{array}{l}\text { May to October mean } \\
\text { temperature }\end{array}$ & $\begin{array}{l}\text { May to October } \\
\text { total rainfall }\end{array}$ & $\begin{array}{c}\text { Absolute maximum air } \\
\text { temperature }\end{array}$ & $\begin{array}{c}\text { Absolute minimum air } \\
\text { temperature }\end{array}$ & $\begin{array}{l}\text { Days observation absolute } \\
\text { max-min temperature }\end{array}$ \\
\hline GP & $\left({ }^{\circ} \mathrm{C}\right)$ & $\mathrm{mm}$ & $\left({ }^{\circ} \mathrm{C}\right)$ & $\left({ }^{\circ} \mathrm{C}\right)$ & days \\
\hline \multicolumn{6}{|c|}{ Climate characteristics } \\
\hline 2016 & $12.3 \pm 7.3^{a}$ & $738^{a}$ & 33.2 & -29.1 & (246 days) \\
\hline 2017 & $12.8 \pm 6.3^{a}$ & $634.6^{a}$ & 30.9 & -34.9 & (240 days) \\
\hline 2018 & $11.9 \pm 8.6^{a}$ & $612.5^{a}$ & 34.9 & -36.9 & (365 days) \\
\hline 2019 & $11.5 \pm 7.2^{\mathrm{a}}$ & $659.2^{\mathrm{a}}$ & 32.7 & -36.5 & (303 days) \\
\hline
\end{tabular}

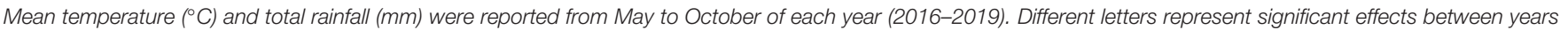

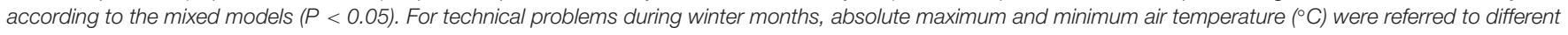

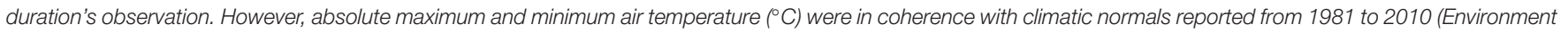
Canada).

after the occurrence of the time-window of needles flushing, when buds are susceptible to defoliation (phases 3-6).

To describe the stem radius variation among different years and between species, we fitted a Gompertz function defined as:

$$
y=A \exp [-\exp (\beta-\kappa \tau)]
$$

where $y$ is the daily stem radius variation, $\tau$ is the time computed in day of the year (DOY), $A$ is the upper asymptote of maximum stem radius variation, $\beta$ is the $x$-axis placement parameter, as time at inflection point of the curve, $\kappa$ is the growth rate of the curve (Camarero et al., 1998; Rossi et al., 2003). The selection of the Gompertz function was based on the lower Akaike information criterion (AIC) and the goodness of fit of the curves was evaluated graphically using the residuals plots of each curve. We then performed a Linear Mixed Models (LMM) with PROC MIXED procedures of SAS 9.4 (SAS Institute, Cary, NC) to assess the effect of year and species, and their interaction the estimates of the coefficients of the Gompertz functions and the stem radius values at the beginning of budburst $(S R F)$. Year and species were considered fixed factors. Then, in the linear mixed models, trees (classified as numeric codes) were included as a random factor and defoliation was used as a covariate.

To assess stem variation radius phases, the stem cycle was extracted using a three-step procedure composed of two SAS routines (SAS 9.4, SAS Institute, Inc., Cary, NC, United States) (Deslauriers et al., 2011). The procedure divides the series into two distinct phases: (1) contraction, the period between the first maximum radius and the following minimum radius; and (2) expansion, considered as recovery period, the period from minimum radius until the return to the previous maximum value or when the stem begins another contraction phase (Turcotte et al., 2009). SAS routines calculated the amount of stem radius variation and the duration of stem cycle phases (Deslauriers et al., 2011). Linear Mixed Model (LMM) was used to analyze differences in the amplitude and duration of the contraction and expansion phases between species and among needles flushing period (before, during, and after), and the species $\times$ needles flushing period interaction. Species and periods were defined as fixed factors, whereas trees (classified as numeric codes) were used as random factor. Defoliation (\%) was included as covariate. For the analysis, we used a linear MIXED model procedure in SAS
(SAS 9.4, SAS Institute, Inc., Cary, NC, United States). The firstorder autoregressive $[\mathrm{AR}(1)]$ provided the suitable correlation structure (Wolfinger, 1993). The selection of the first-order autoregressive $[\mathrm{AR}(1)]$ structure was based on the lower AIC. We evaluated normality and homoscedasticity graphically using the residuals plots of the linear models (Quinn and Keough, 2002).

We also ran linear mixed models to evaluate the effect of years on temperature and rainfall. In all analyses, when fixed-effects were significant, we ran least squares means (LS-means) with Student's $t$-tests for paired comparisons and Tukey-Kramer tests for comparing multiple means.

\section{RESULTS}

\section{Site Environmental Conditions}

From 2016 until 2019, mean air temperature reached around $10^{\circ} \mathrm{C}$, with total rainfall between 620 and $750 \mathrm{~mm}$ during the growing season (Table 1). During the growing season (MayOctober), temperatures were similar overall the years (Table 1). The absolute minimum and maximum temperature reached -37 and $35.3^{\circ} \mathrm{C}$ in 2018 compared to other years.

\section{Phenological Synchrony of Plant Flushing and Insect Feeding}

Over the years, the range of the optimal stage of feeding larvae (SBW) and optimal needle flushing stages for colonizing buds varied between about 41 and 29 days, respectively (Figure 1). On black spruce, the occurrence of optimum larvae stage was observed a few days after the optimal needle flushing stage (5.75 \pm 3.3 days), while there was a longer gap on balsam fir; indeed, the SBW optimal stage arrived $12.5 \pm 4.2$ days after host flushing (Figure 1). In 2016 and 2017, we observed slightly earlier needles flushing phases than the beginning of larval stages in black spruce. In balsam fir, while the flushing period and the feeding larvae began at the same time, the flushing period ended $\sim 24$ days before the end of feeding larvae. In 2018, probability of occurrence of both opening and ending of black spruce flushing was well synchronized with larval phenology, while in balsam fir flushing was 11 days before larvae started intensive feeding activity. In 2019, we observed a low and, 


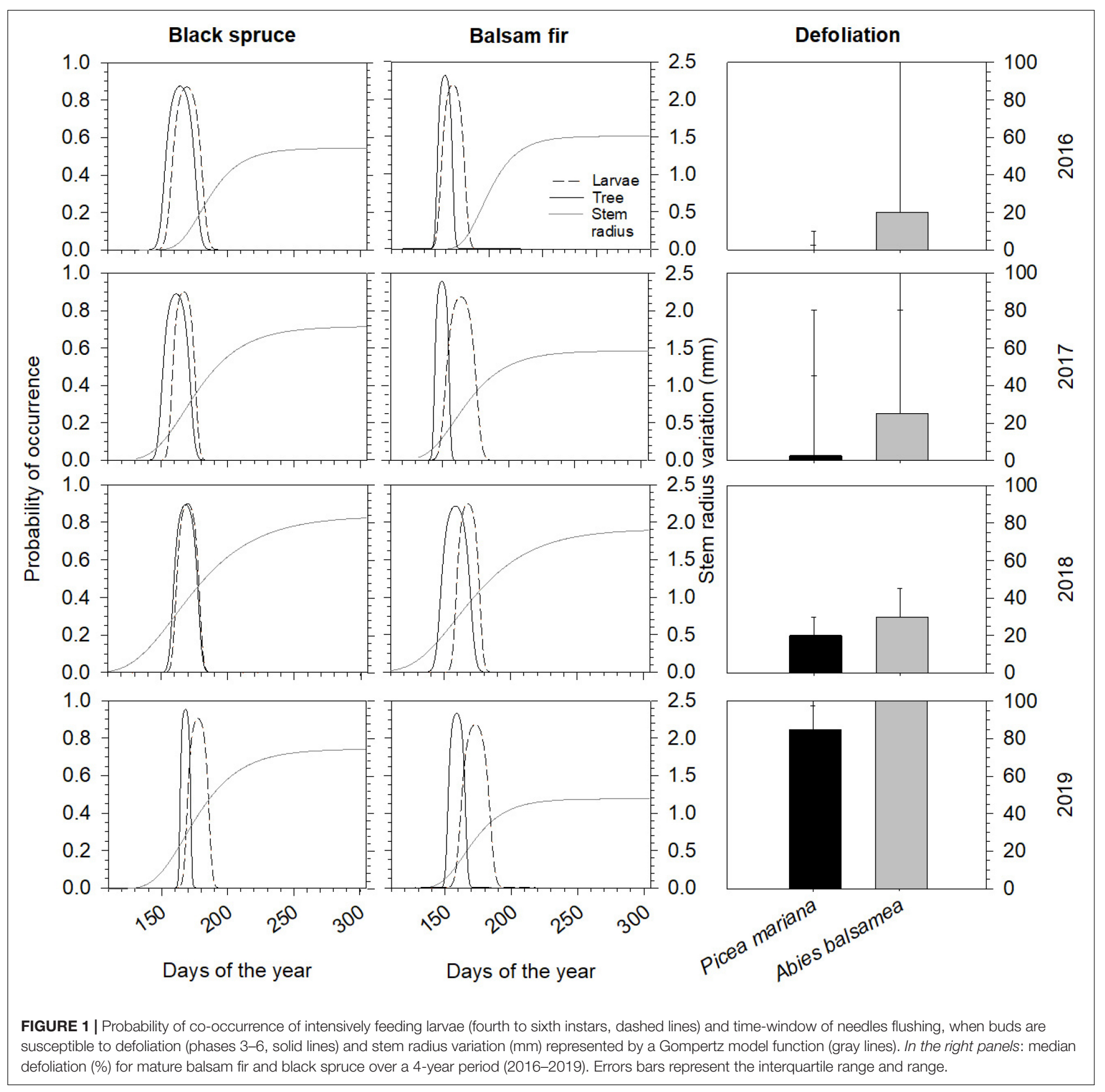

respectively, high (2-3 weeks delay) phenological mismatch in black spruce and balsam fir.

From 2016 to 2019, there was an increase in the defoliation levels for both species (Figure 1). In 2016, we observed the first signs of defoliation in balsam fir (20\% of new shoots defoliated), while it remained negligible in spruce (well under 10\%). Later it increased to moderate values in 2017, and even more in 2018, when median annual values reached 20 and $30 \%$ in black spruce and balsam fir, respectively. Finally, in 2019, both species were severely defoliated, with $80 \%$ in black spruce and as much as $100 \%$ in balsam fir (Figure 1).

\section{Variation of Stem Radius in Defoliated Trees}

Over the four study years, both species showed similar seasonal patterns in radial growth (Figure 1) with a fast increase from the end of April and beginning of May to mid-July (from DOY 120-130 to DOY 201), then a progressive transition to a plateau reached in fall (DOY 304). No significant effects of species, year, of their interaction and of defoliation were observed on two coefficients of the Gompertz function, the upper asymptote (A) and non-linear rate of growth (к) (Table 2). Despite the low number of trees, the high accuracy of the dendrometer 
TABLE 2 | Results of the mixed models showing the effects of years, species, and their interaction on Gompertz coefficients ( $A$, upper asymptote of maximum stem radius variation; $\beta, x$-axis placement parameter; $\kappa$, growth rate of the curve; $S R F$, stem radius values at the beginning of needles flushing for black spruce and balsam fir using as fixed factors.

\begin{tabular}{|c|c|c|c|c|c|c|c|c|c|}
\hline \multirow[t]{2}{*}{ Source of variation } & \multirow[b]{2}{*}{ df } & \multicolumn{2}{|c|}{$\boldsymbol{A}$} & \multicolumn{2}{|c|}{$\beta$} & \multicolumn{2}{|c|}{$\kappa$} & \multicolumn{2}{|c|}{ SRF } \\
\hline & & $F$-value & $P$ & $F$-value & $\boldsymbol{P}$ & $F$-value & $P$ & $F$-value & $P$ \\
\hline Year & 3 & 3.45 & 0.0551 & 3.66 & 0.0476 & 3.34 & 0.0597 & 3.79 & 0.0435 \\
\hline Species & 1 & 0.93 & 0.3557 & 0.79 & 0.3918 & 1.53 & 0.2418 & 13.36 & 0.0038 \\
\hline Year $\times$ Species & 3 & 2.08 & 0.1614 & 0.21 & 0.8866 & 0.1 & 0.9586 & 0.89 & 0.4781 \\
\hline Defoliation & 1 & 2.79 & 0.1228 & 7.27 & 0.0208 & 0.78 & 0.3956 & 13.18 & 0.0040 \\
\hline
\end{tabular}

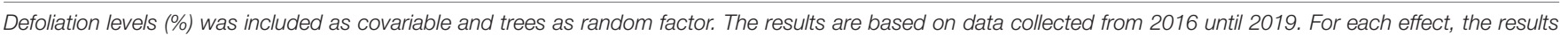
include the degree of freedom (df), F-statistic (F), and probability $(P)$. Significant effects $(P \leq 0.05)$ are highlighted in bold.
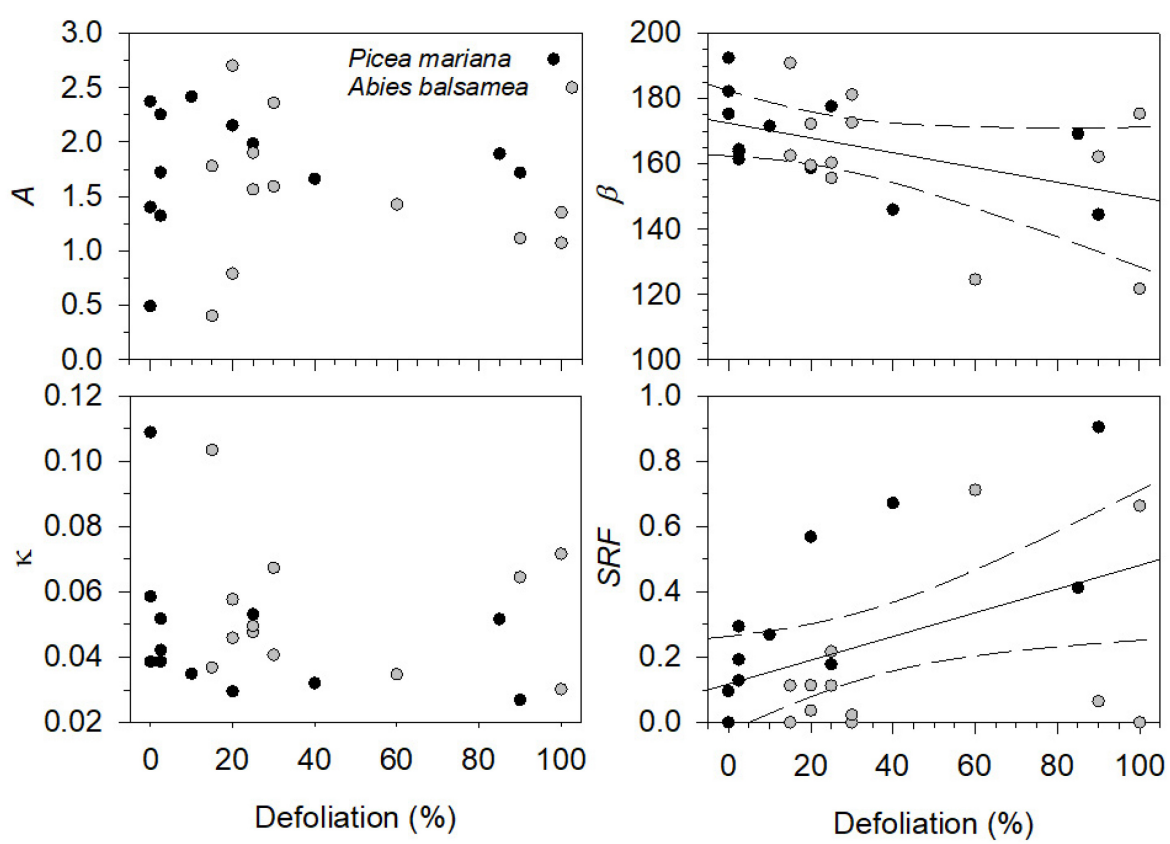

FIGURE 2 | Defoliation (\%) effects on Gompertz parameters [upper asymptote of maximum stem radius variation ( $A$ ), inflection point parameter ( $\beta$ ), growth rate of the curve $(\kappa)$ ] and stem radius value at the beginning of needles flushing (SRF, $\mathrm{mm}$ ) for black spruce and balsam fir. The solid lines refer to the estimated marginal means of $\beta$ and SRF adjusted for the defoliation in linear mixed models and the dashed lines represent the 95\% confidence interval, when the defoliation was significant.

measurements allowed to highlight significant differences. In particular, significant effects of years $(P=0.0476$, Table 2$)$ and defoliation ( $P=0.0208$, Table 2 ) were found on the coefficient $\beta$ (inflection point of the growth response curve). However, no significant differences among years were observed anymore when multiple comparison correction by Tukey-Kramer'smethod was applied. Defoliation had a significant and negative effect on $\beta$, meaning that an increase in defoliation corresponded to an earlier $\beta(P=0.0208$, Table 2$)$. Furthermore, the stem radius expansion at the beginning of needle flushing $(S R F)$ was significantly affected by all factors except the interaction (Table 2), meaning that although species responded similarly at the end of the growing season, stem radius responded strongly to species and defoliation effects in the first phases of needle flushing. The values of stem radius expansion at the beginning of needle flushing was significantly lower in balsam fir compared to black spruce, with 0.06 and $0.42 \mathrm{~mm}$, respectively $(P=0.0038$, Table 2$)$. On the contrary, the defoliation had a significant and positive effect on stem radius values $(P=0.004$, Table 2$)$ : an increase in defoliation corresponded to an increase in stem radius at the beginning of needles flushing (Figure 2). Even if a significant effect of the year was observed on $\operatorname{SRF}(P=0.0435$, Table 2), no difference in stem radius expansion at the onset of needles flushing was detected from 2016 to 2019 (after multiple comparison correction by Tukey-Kramer's method).

\section{How Does Diurnal Stem Fluctaions Respond to Needles Flushing and Defoliation?}

The species significantly modified the amplitude of contraction and expansion according to the different periods, before, during and after needles flushing (Table 2). The amplitude of stem contraction and expansion was significantly higher in black 
spruce compared to balsam fir (LSM, 0.09 and $0.06 \mathrm{~mm}$ in spruce vs. 0.04 and $0.02 \mathrm{~mm}$ in fir, respectively) (Figure 3). The needles flushing period influenced only the amplitude of stem expansion, but not the contraction. The amplitude of stem expansion was significantly lower before flushing compared to during flushing (LSM, 0.03 vs. $0.05 \mathrm{~mm}$ ) (Figure 3). However, we observed no significant difference in the amplitude of contraction and expansion in the combination of flushing $\times$ species, and according to the defoliation level (Table 2).

The duration of stem contraction and expansion was influenced by the flushing period and defoliation effects (Table 3). The duration of stem contraction after flushing was significantly lower than before and during bud development (LSM, $7.5 \mathrm{~h}$ vs. 10.6 and 9.5 h, respectively) (Figure 3). A significant difference in stem expansion duration was also found between, before and during the flushing as well as between, before and after the flushing (Table 3). The duration of expansion before flushing was significantly higher than during bud development (LSM, 13 h vs. 9) (Figure 3). However, we found no differences in the duration of contraction and expansion between species and for the flushing $\times$ species interaction (Table 3 and Figure 3 ).

Furthermore, significant differences in the duration of stem contraction and expansion were found according to the defoliation level. In the pooled raw data, mean values of the duration of contraction were $8.5 \mathrm{~h}$ in the low-moderate defoliation levels, whereas they slightly increased to $9 \mathrm{~h}$ in higher levels of defoliation (Figure 3). In the pooled raw data, mean values of duration of expansion were around $10-11 \mathrm{~h}$ in the low defoliation levels, whereas they decreased to $9 \mathrm{~h}$ in the severe defoliation levels (Figure 3).

\section{DISCUSSION}

\section{Defoliation Effects on Stem Radius Variation}

This study investigated seasonal stem radius variation of black spruce and balsam fir during 4 years of natural defoliation by spruce budworm. We expected that a higher level of defoliation would reduce seasonal stem radius variations such as in young trees in controlled conditions (Deslauriers et al., 2019). However, in the mature trees in natural conditions of this study, we detected a decreasing trend in seasonal stem radius variation only in balsam fir during the fourth defoliation year, thus partially contradicting the first hypothesis. Since branches perform as semi-independent compartments (Sprugel et al., 1991), water reserve stored in roots and stems sustains woody and leaf tissues with a given pressure during high evaporative periods (Scholz et al., 2007; Meinzer et al., 2008). Under longer term droughts, stored water acts as a safety buffer more efficiently in adult trees than in saplings (Phillips et al., 2003), limiting the damage to stem growth. Specific soluble sugars (i.e. sucrose raffinose and pinitol) were then required for osmoregulation to prevent hydraulic failure (Hölttä et al., 2006; Deslauriers et al., 2014; Sevanto et al., 2014). However, under different stress conditions such as defoliation, needles damage or loss after larval feeding had a minimal or no effect on water loss
(Quentin et al., 2011; Bouzidi et al., 2019). An increased leaf water content and reduced evapotranspiration (Balducci et al., 2020) are required to counteract the reduction of turgor pressure due to needle removal. Therefore, in the case of defoliation, increased water uptake and stem growth could take place until carbon remobilization from plants parts could act also as a safety buffer for stem growth in the first years of consecutive defoliation. Indeed, defoliation did not affect two of the three estimated Gompertz parameters ( $A$ and $\kappa$ ), whereas the third one, $\beta$, was significantly affected by year and defoliation. Furthermore, a significant increase in stem radius expansion $(S R F)$ at the beginning of the needles flushing was observed in the increased defoliation level. In fact, during and after flushing, heavy defoliation removes all or most of current-year needles. Previous studies observed a temporary slowdown of stem growth and hypothesized an effect of budburst phenology (Belien et al., 2014; Balducci et al., 2019) due to C-sink competition between bud development and stem growth (Deslauriers et al., 2016; MartínezVilalta et al., 2016).

There was no significant variation over time for parameter $A$, showing that in the first 4 years of defoliation both species were able to maintain their stem radius without major effects of defoliation for the remainder of the growing season. Despite this, the sharp decrease of stem radius in balsam fir in the fourth year could be due to intensity and duration of defoliation and age response. Previous work in young trees showed that stem radius decreased when starch levels were significantly depleted in the needles, branchlet, and roots after 2 years of heavy defoliation (Deslauriers et al., 2019). We could expect a more delayed response after several successive years of defoliation in mature than in young trees, due to age differences in different hydraulic safety behaviors and C-dynamic (Domec and Gartner, 2002; Hartmann and Trumbore, 2016). Indeed, under favorable conditions, a bigger fraction of water and C-reserve is generally stored in mature trees than in young trees (Domec and Gartner, 2002; Martínez-Vilalta et al., 2016). But mature trees operate nearest to xylem dysfunction compared to young trees (Domec and Gartner, 2002). Moreover, during defoliation mature trees showed a narrower safety margin to cavitation than young trees, compromising hydraulic integrity and efficiency (Hillabrand et al., 2019), although C-stocks can be remobilized for regrowth after stress conditions (Carbone et al., 2013).

Contrary to the other Gompertz parameters, $\beta$ was responsive to year and defoliation, indicating an earlier occurrence of the inflection points at higher defoliation levels. Our finding suggests an earlier end of the exponential increase of stem radial growth, particularly when defoliation is high. Interannual changes in stem radius variation are regulated by a mixture of current or delayed abiotic effects (temperature, precipitation, cloud cover) (King et al., 2013; Vieira et al., 2013). A previous study suggests that the convergence observed in host and insect phenology under warmer temperatures increases food quantity and quality for the foraging insects (Ren et al., 2020). In this study, we observed cooccurrence of host-insect stages over the years, although their peaks did not perfectly overlap in 2018 and 2019 in balsam fir. Reduced synchrony in balsam fir could protect the species against the severe -defoliation (Nealis and Régnière, 2004). The 

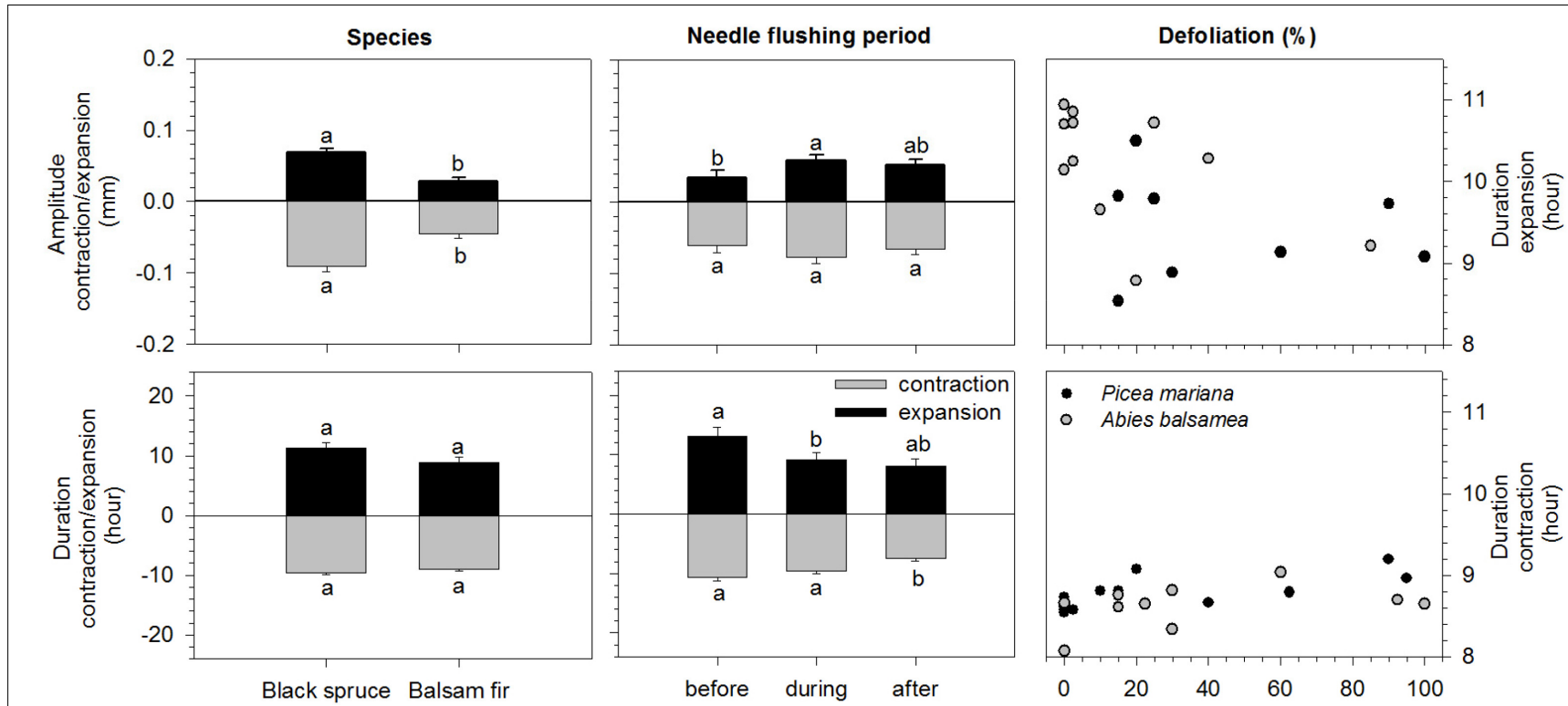

FIGURE 3 | Results of mixed models (LS-means) of amplitude (mm) and duration (hours) of the contraction and expansion phases of black spruce (Picea mariana) and balsam fir (Abies balsamea) before during and after needles flushing. Error bars correspond to error type and different letters correspond to significant differences between species and among needles flushing periods. In the right panels: defoliation effects on the duration (hours) of the contraction and expansion phases of black spruce (black circles) and balsam fir (gray circles).

TABLE 3 | Results of the mixed models showing the effects of needles flushing period (before, during, and after), species, and their interaction, as fixed factors, on

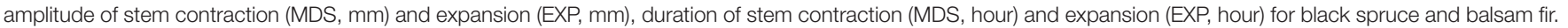

\begin{tabular}{|c|c|c|c|c|c|c|c|c|c|}
\hline \multirow[t]{2}{*}{ Source of variation } & \multirow[b]{2}{*}{ df } & \multicolumn{2}{|c|}{ Amplitude MDS } & \multicolumn{2}{|c|}{ Amplitude EXP } & \multicolumn{2}{|c|}{ Duration MDS } & \multicolumn{2}{|c|}{ Duration EXP } \\
\hline & & $F$-value & $P$ & $F$-value & $P$ & $F$-value & $P$ & $F$-value & $P$ \\
\hline Flushing period & 2 & 1.31 & 0.274 & 4.13 & 0.022 & 6.39 & 0.002 & 5.34 & 0.008 \\
\hline species & 1 & 20.22 & $<0.0001$ & 37.45 & $<0.0001$ & 1.07 & 0.304 & 3.73 & 0.059 \\
\hline Flushing period $\times$ species & 2 & 1.91 & 0.154 & 2.12 & 0.131 & 0 & 0.997 & 0.73 & 0.488 \\
\hline Defoliation & 1 & 0.83 & 0.364 & 0 & 0.984 & 5.19 & 0.025 & 4.33 & 0.043 \\
\hline
\end{tabular}

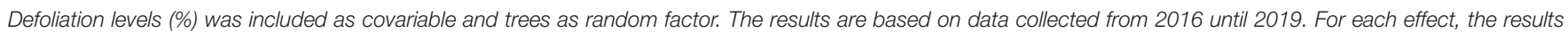
include the degree of freedom (df), F-statistic (F), and probability $(P)$. Significant effects $(P \leq 0.05)$ are highlighted in bold.

year effect on $\beta$ could be potentially masked and influenced by the occurrence of insect feeding. However, it is known that defoliation reduces water safety and efficiency (Hillabrand et al., 2019) and could reduce the mechanical strength of the thickwalled tracheids via impairing the $\mathrm{C}$ source-sink relationships. Defoliation advanced needle flushing and reduced radial growth in young trees (Deslauriers et al., 2019). Needle flushing is a high priority event to ensure new carbon assimilation for the coming growing season. In case of defoliation, newly assimilated $\mathrm{C}$ is primarily allocated to primary growth and crown recovery rather than to secondary growth. However, growth reduction in tree rings, with a typical " $U$ " or "V" shape damage of tree rings due to lower ring width, was observed only after 5 years of heavy defoliation (Simard et al., 2008). This suggests that xylem conduits could be deformed and this deformation could affect water transport, although they could have enough C-resources to grow for several years, as suggested by our findings on parameter $A$. However, similarly to young trees, mature trees experienced an earlier needle flushing after 1 year of defoliation
(Fuentealba et al., 2017a). The feeding activity may induce high pressure on bud and needles availability in the next season, predetermining growth conditions. In our study, the earlier time of inflection of the stem radial growth curve could signal a pattern of growth compensation, which could be changed by an adverse effect of defoliation.

\section{Modulation of Diurnal Contraction and Expansion Fluctuations}

An alteration of the daily cycle of stem contraction and expansion (especially of their duration) with defoliation is consistent with our first hypothesis. This result suggests that contraction lasted longer, and that water repletion was faster at the higher defoliation levels. The consequence is a continued rapid radial growth at the time of needles flushing. Similar modulation (increase/decrease) of duration of cyclic contraction/expansion was observed under water deficit (Zweifel et al., 2005) in concomitance with a negative/positive shift in 
predawn water potential (Balducci et al., 2019). An imbalance between transpiration demand and water uptake could explain this (Herzog et al., 1998; Meinzer et al., 2008). However, during and after severe defoliation of apical shoots, a higher transpiration demand is generally combined with a decrease in midday water potential (Eyles et al., 2013; Salmon et al., 2015). Yet the reduction of leaf area due to defoliation, even if it constrains transpiration, was not enough to significantly reduce the relative water content (RWC) (Balducci et al., 2020). Previous works support the idea that RWC reflects the balance between leaf tissue water supply and transpiration rate (Meinzer et al., 2003, 2014). Hence, the respective increase/decrease of contraction/expansion duration may reveal that mechanisms acting within diurnal fluctuation mediate response of internal water status to defoliation.

Our second hypothesis (in defoliated trees, during the needles flushing time-window, the amplitude and duration of daily contraction and expansion are reduced) was not supported by the results. Needles flushing period influenced all phases of stem radius variation, except the amplitude of contraction. In this study, the increase in the amplitude of expansion during flushing explained the higher SRF at the time of flushing (see previous section). Earlier spring stem rehydration associated to earlier snowmelt could explain this (Rossi et al., 2011). A recent study demonstrated that soil temperature and mean daily surface temperature significantly increased the number of enlarging tracheids in our species (Chen et al., 2019). Thus, favorable environmental conditions could increase reversible stem expansion before irreversible stem radial growth.

\section{Species Contrasting Response to Defoliation}

Differences in the species response to defoliation was partly expected (third hypothesis). The amplitudes of stem radius variation were higher in black spruce than in balsam fir over the 4-year defoliation period. Previous studies showed that mature black spruce and balsam fir showed similar amplitudes of stem variations, ranging between 0.9 and $2 \mathrm{~mm}$ (Deslauriers et al., 2003; Belien et al., 2014). In our study, balsam fir reduces the amplitude of stem variation more than black spruce; this suggests that balsam fir could prioritize the production of new epicormic and lateral shoots to overcompensate for needle losses by insect feeding (Piene, 1989a,b; Piene and Little, 1990). The species effect was also significant on SRF at the beginning of needle flushing. Balsam fir had a lower $S R F$ than black spruce at the beginning of needle flushing, indicating that secondary growth slowed down during the flushing period in balsam fir.

However, we did not observe any difference in the durations of the diurnal fluctuation of stem radius variation between the species. Before 2016, when SBW was not observed in our site, the duration of xylogenesis (irreversible radial growth) and number of enlarging cells were also similar between the species (Chen et al., 2019), suggesting that water availability in wood tissues and turgor pressure process (cell expansion) were adequate. However, when defoliation started, balsam fir showed a smaller hydraulic safety margin compared to black spruce (Balducci et al., 2020). This suggests that these species have different behavior of daily radial variation over time to sustain growth waterdriven process. An earlier flushing compared to the timing of insect emergence was recently observed in both species after severe defoliation (Deslauriers et al., 2019; Ren et al., 2020). This implies that in the case of higher allocation of sugar compounds to buds, trees might live at the limit of hydraulic failure to favor chemical defense, primary and root growth and defense strategies over replenishment of stem growth reserves (Körner, 2003; Deslauriers et al., 2015, 2019). We observed a lower defoliation level in black spruce than in balsam fir over 4 years. This result suggests that black spruce had not yet attained the critical defoliation values that suppress stem radial variation, as observed in previous studies (Bouzidi et al., 2019; Deslauriers et al., 2019).

\section{CONCLUSION}

This study offers new insights to understand the ongoing effect of defoliation over a 4-year period. The results of the study suggest that while seasonal variation of stem radius is not limited by defoliation over four successive years, the signaling of mild defoliation on reversible and irreversible processes is mediated by the duration and amplitude of expansion/contraction. The duration of diurnal expansion/contraction can be considered as a key trait signaling the severity of biotic stresses before significant stem growth reduction.

\section{DATA AVAILABILITY STATEMENT}

The original contributions presented in the study are included in the article, further inquiries can be directed to the corresponding author/s.

\section{AUTHOR CONTRIBUTIONS}

$\mathrm{AD}$ designed the study and contributed to the funding. AD and $\mathrm{PR}$ provided the resources, reviewed, and edited the manuscript. LB analyzed the data, drafted and edited the manuscript. All authors contributed to the article and approved the submitted version.

\section{FUNDING}

This study was funded by the Programme de Financement de la Recherche et Développement en Aménagement Forestier of the Quebec Province (MFFP). LB was funded by the MITACS Accelerate Fellowship in collaboration with SOPFIM (Société de protection des forêts contre les insectes et maladies/Forest protection society against insects and disease).

\section{ACKNOWLEDGMENTS}

We thank F. Gionest, A. Ferland-Roy from SEPAQ and V. Néron, I. Froment for technical support in data collection. We thank to D. Emond for technical advice. 


\section{REFERENCES}

Balducci, L., Deslauriers, A., Rossi, S., and Giovannelli, A. (2019). Stem cycle analyses help decipher the nonlinear response of trees to concurrent warming and drought. Ann. For. Sci. 76:88. doi: 10.1007/s13595-019-0870-7

Balducci, L., Fierravanti, A., Rossi, S., Delzon, S., De Grandpré, L., Kneeshaw, D. D., et al. (2020). The paradox of defoliation: declining tree water status with increasing soil water content. Agric. For. Meteorol. 290:108025. doi: 10.1016/j. agrformet.2020.108025

Belien, E., Rossi, S., Morin, H., and Deslauriers, A. (2014). High-resolution analysis of stem radius variations in black spruce [Picea mariana (Mill.) BSP] subjected to rain exclusion for three summers. Trees 28, 1257-1265.

Bouzidi, H. A., Balducci, L., Mackay, J., and Deslauriers, A. (2019). Interactive effects of defoliation and water deficit on growth, water status, and mortality of black spruce (Picea mariana (Mill.) B.S.P.). Ann. For. Sci. 76:21. doi: 10.1007/s13595-019-0809-z

Camarero, J. J., Guerrero-Campo, J., and Gutiérrez, E. (1998). Tree-ring Growth and Structure of Pinus uncinata and Pinus sylvestris in the Central Spanish Pyrenees. Arctic and Alpine Research 30, 1-10. doi: 10.1080/00040851.1998. 12002869

Candau, J., Fleming, R. A., and Hopkin, A. (1998). Spatiotemporal patterns of large-scale defoliation caused by the spruce budworm in Ontario since 1941. Can. J. For. Res. 28, 1733-1741. doi: 10.1139/x9 8-164

Carbone, M. S., Czimczik, C. I., Keenan, T. F., Murakami, P. F., Pederson, N., Schaberg, P. G., et al. (2013). Age, allocation and availability of nonstructural carbon in mature red maple trees. New Phytol. 200, 1145-1155. doi: 10.1111/ nph. 12448

Chen, L., Rossi, S., Deslauriers, A., and Liu, J. (2019). Contrasting strategies of xylem formation between black spruce and balsam fir in Quebec, Canada. Tree Physiol. 39, 747-754. doi: 10.1093/treephys/tpy151

Cooke, B. J., Nealis, V. G., and Régnière, J. (2007). “15 - Insect Defoliators as Periodic Disturbances in Northern Forest Ecosystems," in Plant Disturbance Ecology, eds E. A. Johnson and K. Miyanishi (Burlington: Academic Press), 487-525. doi: 10.1016/b978-012088778-1/50017-0

De Schepper, V., Van Dusschoten, D., Copini, P., Jahnke, S., and Steppe, K. (2012). MRI links stem water content to stem diameter variations in transpiring trees. J. Exp. Bot. 63, 2645-2653. doi: 10.1093/jxb/err445

De Swaef, T., Van Meulebroek, L., Steppe, K., Driever, S. M., Vanhaecke, L., and Marcelis, L. F. M. (2013). Understanding the effect of carbon status on stem diameter variations. Ann. Bot. 111, 31-46. doi: 10.1093/aob/mc s233

Deslauriers, A., Beaulieu, M., Balducci, L., Giovannelli, A., Gagnon, M.-J., and Rossi, S. (2014). Impact of warming and drought on carbon balance related to wood formation in black spruce. Annals of Botany 114, 335-345. doi: 10.1093/ aob/mcul11

Deslauriers, A., Caron, L., and Rossi, S. (2015). Carbon allocation during defoliation: testing a defense-growth trade-off in balsam fir. Front. Plant Sci. 6:338. doi: $10.3389 /$ fpls.2015.00338

Deslauriers, A., Fournier, M.-P., Cartenì, F., and Mackay, J. (2019). Phenological shifts in conifer species stressed by spruce budworm defoliation. Tree Physiol. 39, 590-605. doi: 10.1093/treephys/tpy135

Deslauriers, A., Huang, J.-G., Balducci, L., Beaulieu, M., and Rossi, S. (2016). The contribution of carbon and water in modulating wood formation in black spruce saplings. Plant Physiol. 170, 2072-2084. doi: 10.1104/pp.15.0 1525

Deslauriers, A., Morin, H., Urbinati, C., and Carrer, M. (2003). Daily weather response of balsam fir (Abies balsamea (L.) Mill.) stem radius increment from dendrometer analysis in the boreal forests of Quebec (Canada). Trees 17, 477-484. doi: 10.1007/s00468-003-0260-4

Deslauriers, A., Rossi, S., Turcotte, A., Morin, H., and Krause, C. (2011). A threestep procedure in SAS to analyze the time series from automatic dendrometers. Dendrochronologia 29, 151-161. doi: 10.1016/j.dendro.2011.01.008

Dhont, C., Sylvestre, P., Gros-Louis, M.-C., and Isabel, N. (2010). Field Guide for Identifying Apical Bud Break and Bud Formation Stages in White Spruce. Quebec: Natural Resources Canada.
Domec, J. C., and Gartner, B. L. (2002). Age- and position-related changes in hydraulic versus mechanical dysfunction of xylem: inferring the design criteria for Douglas-fir wood structure. Tree Physiology 22, 91-104. doi: 10.1093/ treephys/22.2-3.91

Eyles, A., Pinkard, E. A., Davies, N. W., Corkrey, R., Churchill, K., O'grady, A. P., et al. (2013). Whole-plant versus leaf-level regulation of photosynthetic responses after partial defoliation in Eucalyptus globulus saplings. J. Exp. Bot. 64, 1625-1636. doi: 10.1093/jxb/ert017

Fuentealba, A., Sagne, S., Pureswaran, D., Bauce, É, and Despland, E. (2017b). Defining the window of opportunity for feeding initiation by second-instar spruce budworm larvae. Can. J. For. Res. 48, 285-291. doi: 10.1139/cjfr-20170133

Fuentealba, A., Pureswaran, D., Bauce, É, and Despland, E. (2017a). How does synchrony with host plant affect the performance of an outbreaking insect defoliator? Oecologia 184, 847-857. doi: 10.1007/s00442-017-3914-4

Gray, D. R., Régnière, J., and Boulet, B. (2000). Analysis and use of historical patterns of spruce budworm defoliation to forecast outbreak patterns in Quebec. For. Ecol. Manage. 127, 217-231. doi: 10.1016/s0378-1127(99)00 134-6

Hart, M., Hogg, E. H., and Lieffers, V. J. (2000). Enhanced water relations of residual foliage following defoliation in Populus tremuloides. Can. J. Bot. 78, 583-590. doi: 10.1139/b00-032

Hartmann, H., and Trumbore, S. (2016). Understanding the roles of nonstructural carbohydrates in forest trees - from what we can measure to what we want to know. New Phytol. 211, 386-403. doi: 10.1111/nph.13955

Herzog, K., Thum, R., Kronfus, G., Heldstab, H.-J., and Häsler, R. (1998). Patterns and mechanisms of transpiration in a large subalpine Norway spruce (Picea abies (L.) Karst.). Ecol. Res. 13, 105-116. doi: 10.1046/j.1440-1703.1998.00 250.x

Hillabrand, R. M., Hacke, U. G., and Lieffers, V. J. (2019). Defoliation constrains xylem and phloem functionality. Tree Physiology 39, 1099-1108. doi: 10.1093/ treephys/tpz029

Hochuli, D. F. (2001). Insect herbivory and ontogeny: how do growth and development influence feeding behaviour, morphology and host use? Austral Ecol. 26, 563-570. doi: 10.1046/j.1442-9993.2001.01135.x

Hölttä, T., Vesala, T., Sevanto, S., Perämäki, M., and Nikinmaa, E. (2006). Modeling xylem and phloem water flows in trees according to cohesion theory and Münch hypothesis. Structure and Function 20, 67-78. doi: 10.1007/s00468-005-0014-6

Hubbard, R. M., Rhoades, C. C., Elder, K., and Negron, J. (2013). Changes in transpiration and foliage growth in lodgepole pine trees following mountain pine beetle attack and mechanical girdling. For. Ecol. Manage. 289, 312-317. doi: 10.1016/j.foreco.2012.09.028

Jacquet, J.-S., Bosc, A., O'grady, A., and Jactel, H. (2014). Combined effects of defoliation and water stress on pine growth and non-structural carbohydrates. Tree Physiol. 34, 367-376. doi: 10.1093/treephys/tpu018

Jacquet, J.-S., Orazio, C., and Jactel, H. (2012). Defoliation by processionary moth significantly reduces tree growth: a quantitative review. Ann. For. Sci. 69, 857-866. doi: 10.1007/s13595-012-0209-0

Jardon, Y., Morin, H., and Dutilleul, P. (2003). Périodicité et synchronisme des épidémies de la tordeuse des bourgeons de l'épinette au Québec. Can. J. For. Res. 33, 1947-1961. doi: 10.1139/x03-108

Jepsen, J. U., Hagen, S. B., Karlsen, S.-R., and Ims, R. A. (2009). Phase-dependent outbreak dynamics of geometrid moth linked to host plant phenology. Proc. $R$. Soc. B Biol. Sci. 276, 4119-4128. doi: 10.1098/rspb.2009.1148

Kalcsits, L., and Northfield, T. (2020). Insect feeding location determines interactions between biotic and environmental stressors in trees. Tree Physiol. 40, 577-579. doi: 10.1093/treephys/tpaa003

Kautz, M., Meddens, A. J. H., Hall, R. J., and Arneth, A. (2017). Biotic disturbances in Northern Hemisphere forests - a synthesis of recent data, uncertainties and implications for forest monitoring and modelling. Glob. Ecol. Biogeogr. 26, 533-552. doi: 10.1111/geb.12558

King, G., Fonti, P., Nievergelt, D., Büntgen, U., Frank, D., King, G., et al. (2013). Climatic drivers of hourly to yearly tree radius variations along a $6^{\circ} \mathrm{C}$ natural warming gradient. Agric. For. Meteorol. 168, 36-46. doi: 10.1016/j.agrformet. 2012.08.002

Körner, C. (2003). Carbon limitation in trees. J. Ecol. 91, 4-17. doi: 10.1111/j.14698137.2007.02079.x 
Lachenbruch, B., and McCulloh, K. A. (2014). Traits, properties, and performance: how woody plants combine hydraulic and mechanical functions in a cell, tissue, or whole plant. New Phytol. 204, 747-764. doi: 10.1111/nph.1 3035

Leather, S. R. (1996). Resistance to foliage-feeding insects in conifers: implications for pest management. Integr. Pest Manag. Rev. 1, 163-180. doi: 10.1007/ bf00130674

MacLean, D. A. (1980). Vulnerability of fir-spruce stands during uncontrolled spruce budworm outbreaks: a review and discussion. For. Chron. 56, 213-221. doi: $10.5558 / \mathrm{tfc} 56213-5$

MacLean, D. A., and Lidstone, R. G. (1982). Defoliation by spruce budworm: estimation by ocular and shoot- count methods and variability among branches, trees, and stands. Can. J. For. Res. 12, 582-594. doi: 10.1139/x8 2-090

Martínez-Vilalta, J., Sala, A., Asensio, D., Galiano, L., Hoch, G., Palacio, S., et al. (2016). Dynamics of non-structural carbohydrates in terrestrial plants: a global synthesis. Ecol. Monogr. 86, 495-516. doi: 10.1002/ecm.1231

McGugan, B. M. (1954). Needle-Mining Habits and Larval Instars of the Spruce Budworm. Can. Entomol. 86, 439-454. doi: 10.4039/ent86 439-10

Meinzer, F. C., Clearwater, M. J., and Goldstein, G. (2001). Water transport in trees: current perspectives, new insights and some controversies. Environ. Exp. Bot. 45, 239-262. doi: 10.1016/s0098-8472(01)00 074-0

Meinzer, F. C., James, S. A., Goldstein, G., Woodruff, D. R., and Mcculloh, K. A. (2003). Whole-tree water transport scales with sapwood capacitance in tropical forest canopy trees. Plant Cell Environ. 26, 1147-1155. doi: 10.1046/j.13653040.2003.01039.x

Meinzer, F. C., Woodruff, D. R., Domec, J.-C., Goldstein, G., Campanello, P. I., Gatti, M. G., et al. (2008). Coordination of leaf and stem water transport properties in tropical forest trees. Oecologia 156, 31-41. doi: 10.1007/s00442008-0974-5

Meinzer, F. C., Woodruff, D. R., Marias, D. E., Mcculloh, K. A., and Sevanto, S. (2014). Dynamics of leaf water relations components in co-occurring iso- and anisohydric conifer species. Plant Cell Environ. 37, 2577-2586. doi: 10.1111/ pce. 12327

Ministère des Forêts de la Faune et des Parcs (2015). Aires Infestées par la tordeuse des bourgeons de l'épinette au Québec en 2014; Version 1.2, QC, Canada: Gouvernement du Québec, Direction de la protection des forêts, 23.

Morin, H. (1994). Dynamics of balsam fir forests in relation to spruce budworm outbreaks in the Boreal Zone of Quebec. Can. J. For. Res. 24, 730-741. doi: 10.1139/x94-097

Nealis, V., and Régnière, J. (2004). Insect-host relationships influencing disturbance by the spruce budworm in a boreal mixedwood forest. Can. J. For. Res. 34, 1870-1882. doi: 10.1139/x04-061

Paixao, C., Krause, C., Morin, H., and Achim, A. (2019). Wood quality of black spruce and balsam fir trees defoliated by spruce budworm: a case study in the boreal forest of Quebec. Canada. For. Ecol. Manage. 437, 201-210. doi: 10.1016/j.foreco.2019.01.032

Phillips, N. G., Ryan, M. G., Bond, B. J., Mcdowell, N. G., Hinckley, T. M., and Cèermák, J. (2003). Reliance on stored water increases with tree size in three species in the Pacific Northwest. Tree Physiology 23, 237-245. doi: 10.1093/ treephys/23.4.237

Piene, H. (1989a). Spruce budworm defoliation and growth loss in young balsam fir: defoliation in spaced and unspaced stands and individual tree survival. Can. J. For. Res. 19, 1211-1217. doi: 10.1139/x89-185

Piene, H. (1989b). Spruce budworm defoliation and growth loss in young balsam fir: recovery of growth in spaced stands. Can. J. For. Res. 19, 1616-1624. doi: 10.1139/x89-244

Piene, H., and Little, C. H. A. (1990). Spruce budworm defoliation and growth loss in young balsam fir: artificial defoliation of potted trees. Can. J. For. Res. 20, 902-909. doi: 10.1139/X90-121

Piene, H., Maclean, D. A., and Wall, R. E. (1981). Effects of spruce budworm-caused defoliation on the growth of balsam fir: experimental design and methodology. Fredericton: Environment Canada, Canada Forestry Service, Maritimes Forest Research Centre.
Pinkard, E. A., Battaglia, M., and Mohammed, C. L. (2007). Defoliation and nitrogen effects on photosynthesis and growth of Eucalyptus globulus. Tree Physiol. 27, 1053-1063. doi: 10.1093/treephys/27.7.1053

Pureswaran, D. S., De Grandpré, L., Paré, D., Taylor, A., Barrette, M., Morin, H., et al. (2015). Climate-induced changes in host tree-insect phenology may drive ecological state-shift in boreal forests. Ecology 96, 1480-1491. doi: 10.1890/132366.1

Quentin, A. G., O'grady, A. P., Beadle, C. L., Worledge, D., and Pinkard, E. A. (2011). Responses of transpiration and canopy conductance to partial defoliation of Eucalyptus globulus trees. Agricultural and Forest Meteorology 151, 356-364. doi: 10.1016/j.agrformet.2010.11.008

Quinn, G., and Keough, M. (2002). Experimental design and data analysis for biologists. Cambridge, UK: Cambridge University Press.

Régnière, J., Lysyk, T. J., and Auger, M. (1989). Population density estimation of spruce budworm, Choristoneura fumiferana (Clem.) (Lepidoptera: tortricidae) on balsam fir and white spruce from $45-\mathrm{cm}$ mid-crown branch tips. Can. Entomol. 121, 267-281. doi: 10.4039/ent121267-3

Ren, P., Néron, V., Rossi, S., Liang, E., Bouchard, M., and Deslauriers, A. (2020). Warming counteracts defoliation-induced mismatch by increasing herbivoreplant phenological synchrony. Glob. Chang. Biol. 26, 2072-2080. doi: 10.1111/ gcb. 14991

Rossi, S., Deslauriers, A., and Morin, H. (2003). Application of the Gompertz equation for the study of xylem cell development. Dendrochronologia 21, 33-39. doi: 10.1078/1125-7865-00034

Rossi, S., Morin, H., and Deslauriers, A. (2011). Multi-scale influence of snowmelt on xylogenesis of black spruce. Arct. Antarct. Alp. Res. 43, 457-464. doi: 10. 1657/1938-4246-43.3.457

Royama, T. (1984). Population dynamics of the spruce budworm Choristoneura fumiferana. Ecol. Monogr. 54, 429-462. doi: 10.2307/1942595

Salmon, Y., Torres-Ruiz, J. M., Poyatos, R., Martínez-Vilalta, J., Meir, P., Cochard, H., et al. (2015). Balancing the risks of hydraulic failure and carbon starvation: a twig scale analysis in declining Scots pine. Plant Cell Environ. 38, 2575-2588. doi: $10.1111 /$ pce. 12572

Saucier, J.-P., Grondin, P., Robitaille, A., Gosselin, J., Morneau, C., Richard, P. J. H., et al. (2009). "Écologie forestière - chapitre 4," in Manuel de Foresterie, Ouvrage Collectif, 2e Édn. ed. Ordre des Ingénieurs Forestiers du Québec (Québec, QC: Éditions MultiMondes), 165-316.

Scholz, F. G., Bucci, S. J., Goldstein, G., Meinzer, F. C., Franco, A. C., and MirallesWilhelm, F. (2007). Biophysical properties and functional significance of stem water storage tissues in Neotropical savanna trees. Plant, Cell \& Environment 30, 236-248. doi: 10.1111/j.1365-3040.2006.01623.x

Sevanto, S., Mcdowell, N. G., Dickman, L. T., Pangle, R., and Pockman, W. T. (2014). How do trees die? A test of the hydraulic failure and carbon starvation hypotheses. Plant, Cell and Environment 37, 153-161. doi: 10.1111/pce.12141

Simard, S., Elhani, S., Morin, H., Krause, C., and Cherubini, P. (2008). Carbon and oxygen stable isotopes from tree-rings to identify spruce budworm outbreaks in the boreal forest of Québec. Chem. Geol. 252, 80-87. doi: 10.1016/j.chemgeo. 2008.01.018

Sprugel, D. G., Hinckley, T. M., and Schaap, W. (1991). The theory and practice of branch autonomy. Annu. Rev. Ecol. Syst. 22, 309-334. doi: 10.1080/09602011. 2020.1782946

Turcotte, A., Morin, H., Krause, C., Deslauriers, A., and Thibeault-Martel, M. (2009). The timing of spring rehydration and its relation with the onset of wood formation in black spruce. Agric. For. Meteorol. 149, 1403-1409. doi: 10.1016/j.agrformet.2009.03.010

Turcotte, A., Rossi, S., Deslauriers, A., Krause, C., and Morin, H. (2011). Dynamics of depletion and replenishment of water storage in stem and roots of black spruce measured by dendrometers. Front. Plant Sci. 2:21. doi: 10.3389/fpls.2011. 00021

Vieira, J., Rossi, S., Campelo, F., Freitas, H., and Nabais, C. (2013). Seasonal and daily cycles of stem radial variation of Pinus pinaster in a drought-prone environment. Agric. For. Meteorol. 180, 173-181. doi: 10.1016/j.agrformet.2013. 06.009

Virgin, G. V. J., and MacLean, D. A. (2017). Five decades of balsam fir stand development after spruce budworm-related mortality. For. Ecol. Manage. 400, 129-138. doi: 10.1016/j.foreco.2017.05.057 
Volney, W. J. A., and Fleming, R. A. (2000). Climate change and impacts of boreal forest insects. Agric. Ecosyst. Environ. 82, 283-294. doi: 10.1016/S0167-8809(00) 00232-2

Wolfinger, R. (1993). Covariance structure selection in general mixed models. Commun. Stat. Simul. Comput. 22, 1079-1106. doi: 10.1080/ 03610919308813143

Zweifel, R., Zimmermann, L., and Newbery, D. M. (2005). Modeling tree water deficit from microclimate: an approach to quantifying drought stress. Tree Physiol. 25, 147-156. doi: 10.1093/treephys/25.2.147

Conflict of Interest: The authors declare that the research was conducted in the absence of any commercial or financial relationships that could be construed as a potential conflict of interest.
Publisher's Note: All claims expressed in this article are solely those of the authors and do not necessarily represent those of their affiliated organizations, or those of the publisher, the editors and the reviewers. Any product that may be evaluated in this article, or claim that may be made by its manufacturer, is not guaranteed or endorsed by the publisher.

Copyright $\odot 2021$ Balducci, Rozenberg and Deslauriers. This is an open-access article distributed under the terms of the Creative Commons Attribution License (CC BY). The use, distribution or reproduction in other forums is permitted, provided the original author(s) and the copyright owner(s) are credited and that the original publication in this journal is cited, in accordance with accepted academic practice. No use, distribution or reproduction is permitted which does not comply with these terms. 